Edu Consilium: Jurnal BK Pendidikan Islam

Vol 2, No. 1, Februari 2021, hlm. 12 - 20

ISSN 2503-3417 (online)

ISSN 2548-4311 (cetak)

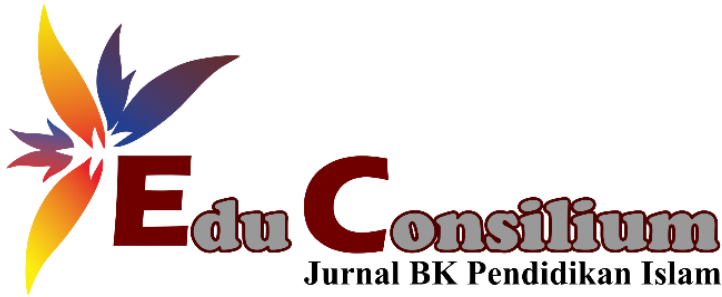

\title{
RESILIENSI PADA GURU HONORER DI MASA PANDEMI
}

\author{
Roziana Amalia $^{1^{*}, \text { Achmad Ainur Ridho }^{2}}$ \\ ${ }^{1}$ Ilmu Al-Qur'an dan Tafsir, STIQ Nurul Islam Karangcempaka Sumenep \\ ${ }^{1}$ Ilmu Al-Qur'an dan Tafsir, STIQ Nurul Islam Karangcempaka Sumenep \\ *e-mail: Roziana.amalia@gmail.com
}

\begin{tabular}{ll}
\hline \hline & Abstract \\
\hline Keywords: & The pandemic swept the world for almost a year. The covid-19 virus spreads globally, \\
Resilience; & including in Indonesia. Teachers also felt the impact of the pandemic. Honorary teachers / \\
Honorary & non-permanent teachers who work in several public and private schools, so far, do not yet \\
teacher; & have a standard salary that focuses on weighted lesson hours. Honorary teachers do face a \\
Pandemic. & worrying reality, starting from the level of unpredictable income, honorary teachers do \\
& not get the allowances provided by the government as do civil servant teachers (PNS). \\
& This study used a phenomenological qualitative research method. The subjects of this \\
& study consisted of 2 teachers in a private school in Sumenep district who had been \\
& honorary teachers for more than 10 years. The results showed that the dynamics of \\
& resilience in honorary teachers can be supported by several factors in the formation of \\
& high resilience, including support from closest people, both from the family, peers, good \\
& social skills, and high religiosity in the form of a pure intention to worship instead of to \\
& profit from teaching.
\end{tabular}

\begin{tabular}{ll}
\hline \hline & Abstrak: \\
\hline Kata Kunci: & Pandemi melanda dunia hampir setahun lamanya. Virus covid-19 menyebar secara global \\
Resiliensi; & tak terkecuali indonesia. Dampak dari pandemi juga dirasakan oleh guru. Guru \\
Guru honorer; & honorer/guru tidak tetap yang bekerja pada beberapa sekolah negeri maupun swasta, \\
Pandemi. & sampai saat ini belum memiliki standar gaji yang menitikberatkan pada bobot jam \\
& pelajaran. Guru honorer memang menghadapi kenyataan yang memprihatinkan, mulai \\
& dari tingkat pengahasilan yang tidak menentu, para guru honorer sama sekali tidak \\
& memperoleh tunjangan-tunjangan yang disediakan oleh pemerintah sebagaimana para \\
& guru pegawai negeri sipil (PNS). Penelitian ini menggunakan metode penelitian kualitatif \\
& fenomenologis Subjek penelitian ini terdiri dari 2 guru di salah satu sekolah swasta di \\
& kabupaten Sumenep yang sudah menjadi guru honorer lebih dari 10 tahun. Hasil \\
& penelitian menunjukkan dinamika resiliensi pada guru honorer dapat didukung oleh \\
& beberapa faktor dalam terbentuknya resiliensi yang tinggi, diantaranya dukungan dari \\
& orang terdekat, baik dari pihak keluarga, teman sejawat, kemampuan social skill yang \\
& baik, serta religiusitas yang tinggi berupa niat yang murni untuk ibadah bukan untuk \\
& mencari keuntungan dari mengajar.
\end{tabular}

CEdu Consilium: Jurnal BK Pendidikan Islam

Bimbingan dan Konseling Pendidikan Islam

Institut Agama Islam Negeri Madura, Indonesia

\section{PENDAHULUAN}

Pandemi melanda dunia nyaris setahun lamanya. Virus yang semula ditemukan di kota Wuhan, Ibukota Provinsi Hubei Cina, serta semenjak itu menyebar secara global tidak terkecuali indonesia. Dampak dari pandemi tidak hanya dari sektor kesehatan, tetapi pula 
pada zona ekonomi, bisnis, bahkan pendidikan. Dampak mewabahnya pandemi covid- 19 secara global mengakibatkan diterapkannya bermacam kebijakan pemerintah yang bertujuan untuk memutus mata rantai penyebaran virus covid- 19 di Indonesia. Upaya yang dicoba oleh pemerintah di Indonesia salah satunya dengan menjalankan himbauan kepada warga supaya melaksanakan physical distancing, yakni himbauan untuk menjaga jarak diantara warga, menghindari kegiatan dalam segala bentuk kerumunan, perkumpulan, serta menjauhi adanya pertemuan yang menyertakan banyak orang. Upaya tersebut diperuntukan kepada warga supaya bisa dilakukan untuk memutus rantai penyebaran pandemi covid- 19 yang terjalin dikala ini. Salah satu wujud physical distancing yang diterapkan pemerintah work from home (WFH) ataupun berkegiatan dari rumah masing-masing termasuk kegiatan pembelajaran. Tenaga pendidik diharuskan melaksanakan pembelajaran berbasis daring. Tetapi terdapat sebagian kebijakan diperbolehkannya melaksanakan pertemuan tatap muka untuk lingkungan pesantren, karena pesantren dianggap daerah streril yang meminimalisir kontak santri dengan dunia luar.

Saat sebelum terdapatnya kebijakan yang memperbolehkan pertemuan tatap muka, pesantren meliburkan santrinya disebabkan keterbatasan fasilitas serta prasarana bila memakai pendidikan daring. Santri yang tinggal di pesantren belajar secara mandiri di pondok begitu pula santri yang tidak tinggal di pesantren belajar mandiri di tiap-tiap rumah. Disebabkan kebijakan tersebut guru-guru pula turut libur. Guru yang berstatus honorer dan Pegawai Negeri Sipil (PNS) ketika pandemi wajib bekerja dari rumah masing-masing. Guru honorer/guru tidak tetap yang bekerja pada sebagian sekolah Negeri ataupun swasta, hingga saat ini belum mempunyai standar pendapatan yang menitikberatkan pada bobot jam pelajaran, tingkatan jabatan, serta tanggung jawab masa depan siswanya. Terlebih buat guru yang mengajar di tingkatan Sekolah Menengah Pertama (SMP) ataupun Sekolah Menengah Atas (SMA). Banyak di antara mereka yang bekerja melebihi dari imbalan yang mereka terima. Dengan kata lain, insentif ataupun pendapatan yang mereka terima tidak sebanding dengan pekerjaan yang mereka laksanakan serta tanggung jawab yang mereka terima terhadap masa depan siswa.

Guru yang berstatus honorer dan pegawai negara sipil (PNS) kala pandemi wajib bekerja dari rumah masing-masing. Guru honorer harus tetap bekerja dengan tugas-tugas yang sama bahkan jauh lebih banya daripada guru honorer. Bauer et al (2006) mengemukakan hasil penelitiannya kalau di negara-negara tumbuh guru ialah profesi yang 
mempunyai tingkatan burnout yang besar. Disamping beban kerja yang berat (Akbar \& Tahoma, 2018).

Guru honorer memanglah mengalami realitas yang memprihatinkan, mulai dari tingkatan pengahasilan yang tidak menentu, para guru honorer sama sekali tidak mendapatkan tunjangan- tunjangan yang disediakan oleh pemerintah sebagaimana para guru pegawai negara sipil (PNS), mengalami keadaan terpuruk bertahun- tahun, mengabdi di daerah serta ditambah status kepegawaianya kurang begitu jelas. Guru honorer wilayah memanglah cendrung terabaikan, sementara itu bagaikan manusia biasa, guru honorer pasti saja mempunyai harapan buat hidup sejahtera. Di sisi lain guru honorer dituntut buat mempunyai pekerjaan sampingan supaya kebutuhannya terpenuhi. Dalam mengalami suasana.

Terdapatnya tekanan hidup untuk guru honorer ini berakibat serius. Perihal tersebut akan lebih parah dengan kepribadian orang yang lemah. Salah satu keahlian yang wajib dipunyai orang dalam mengalami suasana tidak mudah yaitu resiliensi. Resiliensi merupakan keahlian untuk menangani serta menyesuaikan diri terhadap peristiwa yang berat ataupun permasalahan yang terjadi dalam kehidupan. Menanggulangi serta menyesuaikan diri artinya bertahan dalam kondisi tertekan, apalagi berhadapan dengan kesengsaraan (adversity) ataupun trauma yang dirasakan dalam kehidupannya (Reivich, K., \& Shatté, 2002). Bersumber pada pemaparan diatas riset ini diperuntukan buat menarasikan secara sistematik gimana dinamika resiliensi pada guru honorer.

\section{METODE}

Metode yang digunakan dalam penelitian ini adalah metode penelitian kualitatif fenomenologis dengan pertimbangan bahwa suatu peristiwa mempunyai arti atau makna tertentu yang tidak dapat diungkap dengan angka atau secara kuantitatif. Fenomenologi merupakan strategi penelitian di mana di dalamnya peneliti mengidentifikasi hakikat pengalaman manusia tentang suatu fenomena tertentu (Creswell, 2012). Fenomena yang terjadi pada guru honorer memang sudah beberapa kali diangkat dalam penelitian lain, namun dalam penelitian ini dapat terlihat sisi lain yang menarik untuk diangkat ke khalayak. Fenomenologi berusaha memahami manusia dari segi kerangka berpikir maupun bertindak pada setiap orang. Hal terpenting dalam penelitian fenomenologi adalah kenyataan yang terjadi sebagaimana yang dibayangkan atau dipikirkan oleh individu-individu itu sendiri (Moleong, L. J., \& Edisi, 2004). Dalam penelitian fenomenologi, peneliti mengesampingkan 
terlebih dahulu pengalaman-pengalaman pribadinya agar ia dapat memahami pengalaman partisipan yang diteliti (Jean, C. D., \& Michael, 2000).

Subjek penelitian ini terdiri dari 2 guru di salah satu sekolah swasta di kabupaten Sumenep yang telah menjadi guru honorer madrasah lebih dari 10 tahun. Penelitian ini menggunakan wawancara sebagai teknik penggalian data yang mengacu pada definisi dan faktor yang membentuk resiliensi dari Reivich dan Shatte.

\section{HASIL}

Subjek FY dan NH adalah guru honorer di salah satu sekolah swasta Islam di Kabupaten Sumenep. FY adalah guru honorer yang telah mengabdi selama 12 tahun dan NH mengabdi selama 14 tahun. Dari wawancara yang telah dilakukan subjek penelitian memiliki kesulitan masing-masing terkait dengan keprofesiannya sebagai guru honorer di masa pandemi ini baik kesulitan dalam keprofesian dan kesulitan finansial.

FY merupakan guru yang sudah berusia 42 tahun dan memiliki 2 orang anak yang menempuh pendidikan di salah satu pesantren terbesar di Jawa timur. Di usianya yang sudah tidak muda, FY tidak memiliki pilihan lain selain menjadi guru honorer atau melinierkan ijazahnya agar bisa mendaftar sebagai guru penerima tunjangan sertifikasi. FY menyampaikan bahwa kesulitan yang paling dirasakan adalah kesulitan mengatur tugasnya sebagai guru honorer yang juga merangkap sebagai wali kelas, majelis pendamping osis (MPO), guru pengganti dan mengajar 26 jam selama seminggu. FY mengeluhkan tugasnya yang jauh lebih banyak daripada guru PNS dan sertifikasi, dengan beban yang begitu banyak namun dengan honorarium 400.000 dan tunjangan 20.000. Beberapa kasus terjadi honor yang sangat dibawah rata-rata dikarenakan sistem gaji guru honorer hanya bergantung pada absen yang dilakukan staf tata usaha sekolah. Jadi ketika staf tata usaha teledor tidak mencatat kehadiran mereka maka otomatis gaji mereka akan berkurang. FY memaparkan bahwa dia telah melinierkan ijazahnya dengan biaya yang tidak sedikit, namun ketika FY akan mendaftarkan diri terkendala di dana PLPG yang pasa tahun ini harus dikeluarkan secara pribadi. Syarat untuk mendapatkan tunjangan sertifikasi adalah ikut serta dalam PLPG selama 6 bulan yang biayanya kurang lebih 11 juta. FY merasa biaya yang harus dikeluarkan bukanlah biaya yang sedikit, dia tidak memiliki pilihan lain kecuali menjalani profesinya sebagai guru honorer.

Kesulitan finansial juga dirasakan oleh FY, selain menjadi guru honorer FY menjadi ibu rumah tangga dan memiliki usaha warung untuk mencukupi kebutuhan finansial 
keluarganya. FY menceritakan bahwa tiga tahun yang lalu melakukan operasi pengangkatan kanker payudara yang dideritanya, FY menderita kanker payudara stadium 4 yang membuat fisiknya tidak sekuat dulu lagi. Walaupun kanker yang bersarang dalam tubuhnya sudah diangkat tidak membuat fisiknya pulih 100\%, FY harus benar-benar bisa mengatur kegiatannya agar tidak berdampak buruk pada fisiknya. Pernah suatu ketika FY drop dikarenakan memforsir tenaganya untuk mengajar dan berjualan. FY bekerja sendiri tanpa ada orang lain yang membantunya, FY menceritakan hanya bisa istirahat 5 jam selama sehari semalam dikarenakan harus memasak menu untuk jualan dan mempersiapkan materi mengajar.

Ketika pandemi, pada 3 bulan pertama pesantren diliburkan dan santri hanya belajar secara mandiri tanpa pembelajaran daring. Selama pandemi juga warung nasi yang menjadi usahanya terpaksa harus tutup dikarenakan pembatasan kegiatan oleh pemerintah. FY menceritakan bahwa bukan hal yang mudah ketika dihadapkan pada masalah tersebut, suaminya yang hanya sebagai kuli bangunan serabutan juga belum mampu memenuhi kebutuhan finansialnya. FY menceritakan bahwa suaminya tidak akan bekerja jika tidak ada orang yang meminta jasanya. Namun hal yang membuat FY kuat dan mampu bertahan adalah kerena niatnya yang kuat untuk mengabdi di almamaternya, mencari barokah dan dia niatkan ibadah. FY juga mengungkapkan jika yang dia cari hanya honor maka dia akan lebih memilih untuk merantau untuk berjulan di kota besar. FY mengungkapkan dukungan keluarganya juga adalah penguat disaat dia dihadapkan pada masalah yang menurutnya tidak mudah. FY memilih tawakkal dan meyerahkan segala urusannya kepada Allah, yang terpenting FY sudah berusaha untuk merubah nasib.

Subjek kedua dalam penelitian ini adalah NH guru honorer di tingkat kelompok bermain selama 14 tahun. NH adalah guru honorer yang memiliki pekerjaan sampingan sebagai ibu rumah tangga. Sebagai guru honorer NH tidak memiliki harapan untuk menjadi PNS atau mendapat tunjangan sertifikasi, sebab guru kelompok bermain hanya tercatat sebagai pendamping anak bukan tenaga pengajar. Setiap hari NH mendampingi anak didiknya bermain dari jam 07.00 WIB sampai 11.00 WIB, setelah melaksanakan tugas mengajarnya NH kembali menjadi ibu rumah tangga dengan tiga orang anak.

NH mengungkapkan bahwa tidak ada patokan jelas untuk gaji guru honorer, namun hal tersebut bukan masalah bagi dia. NH juga menyampaikan kepada seluruh guru yang ada di unit kelompok bermain bahwa belum ada patokan yang jelas mengenai nominal honor. Jika ada bantuan atau tunjangan maka dibagi rata. NH juga menjelaskan bahwa untuk honor 
pembagiannya sangat tidak menentu, terkadang setiap bulan atau setahun sekali, tergantung dari adanya pendanaan. NH meniatkan semuanya untuk ibadah, jadi seberat apapun dia kembalikan pada sang maha pengatur segalanya. NH bersyukur diberikan kesempatan untuk mengamalkan ilmu yang dia dapat terlebih dia dipercaya sebagai kepala sekolah. Mengajar menjadi salah satu cara NH mengatasi kepenatan di rumahnya.

NH mengungkapkan bahwa tidak ada perbedaan yang signifikan antara masa pandemi dan non pandemi, dirinya senantiasa mendampingi anak-anak bermain. NH menceritakan bukan hal yang mudah untuk menjadi tenaga pengajar di tingkat pendidikan anak usia dini, dia dituntut untuk mampu menghadapi berbagai macam karakter anak. NH seringkali menemukan kendala ketika harus mengaplikasikan berbagai macam metode pada anak, apalagi dengan adanya keterbatasan pada alat peraga permainan. Belum lagi jika dihadapkan dengan permasalahan dengan wali murid dengan beranekaragam karakter.

Ketika sekolah libur ketika pandemi maka NH memberikan tugas belajar secara berkala kepada wali murid untuk dikirim ke grup yang sudah dibuat. NH mengungkapkan bahwa memang sekolah daring lumayan menghabisakan banyak kuota internet, sedangkan disisi lain dia tidak mendapatkan honor dari sekolah. Namun NH mempunyai keyakinan bahwa semua proses yang dia jalani adalah jalan takdir yang sudah digariskan Allah. NH juga menceritakan bahwa komunikasi, kerjasama antar guru menjadi kunci nyamannya iklim di lingkungan sekolah, sehingga honor bukan menjadi patokan utama. Jika salah satu guru mendapatkan rejeki maka akan dibagi bersama. Intinya saling berbagi sesama, jika ada masalah dikomunikasikan bersama.

\section{PEMBAHASAN}

Menurut Reivich dan Shatte (Reivich, K., \& Shatté, 2002), resiliensi adalah kemampuan untuk mengatasi dan beradaptasi terhadap kejadian yang berat atau masalah yang terjadi dalam kehidupan. Bertahan dalam keadaan tertekan, dan bahkan berhadapan dengan kesengsaraan (adversity) atau trauma yang dialami dalam kehidupannya.

Dari penelitian yang sudah dipaparkan di atas, subjek penelitian mempunyai kemampuan resiliensi yang baik. Subjek mampu beradaptasi dengan rasa tidak nyaman yang terjadi dalam kehidupannya serta mampu mengendalikan emosi yang dialaminya. Selain hal tersebut subjek juga mampu mengambil aspek positif dari setiap kejadian yang telah menimpanya. 
Penelitian tersebut juga menjelaskan faktor yang mendukung terbentuknya resiliensi pada dua subjek penelitian adalah faktor religiusitas yang ada dalam diri subjek (internal). Subjek yang memiliki religiusitas tinggi cenderung pasrag dan menyerahkan segala yang dialaminya selama ini adalah kehendak Allah dan membawa manfaat dikemudian hari keyakinan ini menjadikan subjek lebih mampu meredam emosi, optimis, dan mampu menyelesaikan masalah dengan tenang (Riza, M., \& Herdiana, 2012).

Seluruh subjek termotivasi untuk mengajar karena panggilan hati, karena ingin mengabdi dan diniatkan untuk ibadah walaupun antara kerja dan honorarium tidak seimbang. Karena diniatkan ibadah maka orientasi yang dicari oleh subjek hanyalah pahala yang kelak akan dia panen di akhirat. Orang yang mentalnya sehat akan merasakan kebahagiaan dalam hidupnya, merasa dirinya berguna, dapat menyesuaikan diri dengan berbagai keadaan sehingga terhindar dari stress dan perilaku yang tercela (Hag, 2011).

Dukungan atau Support dari keluarga serta teman sesama guru juga membantu dalam terbentuknya resiliensi. Segala sesuatu yang terjadi dalam keluarga akan memengaruhi sehat tidaknya perkembangan seseorang, baik fisik maupun psikologis (Wiwin Hendriani, 2018). Resiliensi berpusat pada prinsip dasar hubungan (Luthar, 2006). Adanya dukungan keluarga membantu seluruh subjek dalam menjalani kegiatan sehari-hari, hubungan yang baik (Maslow, 1970) dengan relasi menunjukkan kebutuhan saling memiliki yang baik (Duffield \& O’Hare, 2020). Resiliensi juga terbentuk dari komunikasi dan terhubung satu sama lain yang positif (Lavigne, G. L., Vallerand, R. J., \& Crevier-Braud, 2011)(Lavigne, Vallerand, \& Crevier-Braud, 2011). Diantara subjek dengan keluarganya terjalin komunikasi positif yang senantiasa memberikan power tersendiri bagi subjek saat menghadapi masa sulit. Dorongan untuk mencari bantuan dari rekan-rekan dan guru menjadi salah satu yang membentuk resiliensi pada guru (Hargreaves, 2000). Keluarga sebagai mikrosistem, sebagai lingkungan yang utama dalam perkembangan individu memiliki kontribusi yang besar terhadap pencapaian resiliensi (W. Hendriani, 2018). Subjek kedua mendapatkan bantuan dari temanteman relasinya baik dari segi finansial maupun dari segi keprofesian.

Penelitian Resilience and Strength yang dilakukan sebelumnya menggambarkan individu yang memiliki resiliensi yang baik, ditunjang oleh faktor keluarga dan kepercayaan yang dia yakini. Individu yang mendapatkan support dari keluarga, akan merancang hidup kedepannya lebih baik untuk membahagiakan keluarga, sedangkan faktor agama, akan membantu memperkuat iman dalam menjalani keimanan sehari-hari (Riza, M., \& Herdiana, 2012). 
Faktor lain yang membuat subjek menjadi resilien adalah optimis ketika menghadapi permasalahan hidup. Semua subjek dalam penelitian ini percaya bahwa tidak ada yang siasia, termasuk mengajar yang diniatkan untuk ibadah. Subjek percaya bahwa banyak pembelajaran hidup yang dia dapat, yang tidak semua orang punya kesempatan belajar lebih seperti dia.

Guru dapat belajar meningkatkan self efficacy (keyakinan akan diri) dan berikutnya akan meningkatkan resiliensi (Day, 2013). Walaupun terkendala untuk belajar secara formal ketika pandemi guru dapat mempelajari hal baru kemudian merefleksikannya yang juga kan bermanfaat untuk meningkatkan resiliensi guru selama pandemi (Duffield \& O’Hare, 2020).

\section{SIMPULAN}

Berdasarkan penjelasan di atas maka dapat disimpulkan bahwa Dinamika resiliensi pada guru honorer terbentuk oleh adanya faktor religiusitas yang ada dalam diri subjek, selanjutnya adanya dukungan sosial dan moril yang diberikan baik dari pihak keluarga, teman sejawat juga meningkatkan resiliensi subjek. Kemampuan social skill dan yang baik, maksudnya interaksi yang terjalin dengan baik dengan sesama guru staf di sekolah, serta religiusitas yang tinggi berupa niat yang murni untuk ibadah bukan untuk mencari keuntungan dari mengajar.

Penelitian ini akan semakin kuat apabila didukung dengan alat ukur yang mampu melihat bagaimana tingkat resiliensi subjek. Melalui data tersesbut akan membantu subjek yakin akan tingkat resiliensi yang diukur dengan angka. Penelitian selanjutnya juga mungkin dapat mengembangkan unit analisis lain yang dapat digali secara umum berkenaan dengan konteks guru honorer dan secara khusus mengenai korelasinya.

\section{DAFTAR RUJUKAN}

Creswell, J. W. (2012). Research Design: Pendekatan Kualitatif, Kuantitatif dan Mixed, terj. Achmad Fawaid. Yogyakarta: Pustaka Pelajar.

Day, C. (2013). The new lives of teachers. In Back to the Future. Brill Sense.

Duffield, S., \& O'Hare, D. (2020). Teacher resilience during coronavirus school closures. In Educational Psychologist AU. The British Psychological Society.

Hag, T. (2011). Psikologi Tasawuf. Pustaka Setia.

Hargreaves, A. (2000). Mixed emotions: Teachers' perceptions of their interactions with students. Teaching and Teacher Education (16 (8)).

Hendriani, W. (2018). Resiliensi psikologis: sebuah pengantar. Kencana.

Hendriani, Wiwin. (2018). Resiliensi psikologis: sebuah pengantar. Kencana.

Jean, C. D., \& Michael, C. F. (2000). Narrative inquiry: Experience and story in qualitative 
research. San Francisco: Jossey-Bass Publishers.

Lavigne, G. L., Vallerand, R. J., \& Crevier-Braud, L. (2011). The fundamental need to belong: On the distinction between growth and deficit-reduction orientations. Personality and Social Psychology Bulletin, 37(9), 1185-1201.

Lavigne, G. L., Vallerand, R. J., \& Crevier-Braud, L. (2011). The fundamental need to belong: On the distinction between growth and deficit-reduction orientations. Personality and Social Psychology Bulletin, 37(9), 1185-1201.

Luthar, S. S. (2006). Resilience in development: A synthesis of research across five decades. Maslow, A. H. (1970). Motivation and personality. New York: Harp and Row.

Moleong, L. J., \& Edisi, P. (2004). Metodelogi Penelitian. Bandung: Remaja Rosdakarya.

Reivich, K., \& Shatté, A. (2002). The resilience factor: 7 essential skills for overcoming life's inevitable obstacles. Broadway books.

Riza, M., \& Herdiana, I. (2012). Resiliensi pada Narapidana Laki-laki di Lapas Kelas 1 Medaeng. Jurnal Psikologi Kepribadian Dan Sosial, 1(3), 142-147. 